\title{
Boron and Marine Life: A New Look at an Enigmatic Bioelement
}

\author{
Carl J. Carrano • Stephen Schellenberg • \\ Shady A. Amin • David H. Green • Frithjof C. Küpper
}

Received: 28 October 2008 / Accepted: 7 March 2009 /Published online: 8 May 2009

(C) The Author(s) 2009. This article is published with open access at Springerlink.com

\begin{abstract}
On the occasion of the 200th anniversary of the discovery of boron, we review the oceanic biogeochemistry of boron as well as suitable analytical techniques for its determination. This overview includes aspects of biogeochemistry including geochemical stable isotope variations, uptake, transport, storage, nutritional value, toxicity, and distribution within biological materials, providing a framework for discussion of the role of boron in marine organisms, which remains largely enigmatic.
\end{abstract}

Keywords AI-2 - Algae - Boromycin · Boron - Nutrient . Biogeochemical cycles · Paleo-pH $\cdot$ Stable isotopes .

Toxicity $\cdot$ Vibrioferrin $\cdot$ Transport

\section{Introduction}

Boron was first isolated by Joseph Louis Gay-Lussac, Louis Jacques Thênard, and Humphry Davy in 1808 (Davy 1808; Gay-Lussac and Thenard 1808, respectively). On the

C. J. Carrano $\cdot$ S. A. Amin

Department of Chemistry and Biochemistry,

San Diego State University,

San Diego, CA 92182-1030, USA

S. Schellenberg

Department of Geological Sciences, San Diego State University,

San Diego, CA 92182-1030, USA

D. H. Green · F. C. Küpper $(\bowtie)$

Microbial and Molecular Biology,

The Scottish Association for Marine Science,

Dunstaffnage Marine Laboratory

Oban, Argyll PA37 1QA, Scotland, UK

e-mail: fck@sams.ac.uk 200th anniversary of this event, we would like to reflect on its role in the ocean and in marine life in particular.

While there has been extensive interest in the use of boron as a surrogate of $\mathrm{pH}$ in paleoclimate studies in the context of climate change-related questions (vide infra), the high $(0.4 \mathrm{mM})$ concentration in seawater and the depthindependent (non-nutrient-like, Fig. 1) concentration profile of this element have led to boron being neglected as a potentially biologically relevant element in the ocean (Uppstrom 1974). However, recent advances in genomics, trace element detection, biochemistry, and natural products discovery have renewed interest in this previously largely neglected element.

Since the 1920s, boron has been known to be an essential micronutrient for all higher terrestrial plants and many other organisms, but also to be toxic at higher environmental concentrations (Warington 1923; Goldbach et al. 2001 for review). Thus, the beneficial range of boron appears rather narrow. A large volume of literature has focused on the element from the perspective of terrestrial agriculture (reviewed by Tanaka and Fujiwara 2008) with established examples of both boron deprivation (Warington 1923) and boron toxicity (Yau et al. 1995). In consequence, both boron-tolerant and boron-efficient cultivars have been developed. In contrast to the generally boron-poor terrestrial environment, the relatively high concentration of boron in the marine environment suggests that boron deficiency is not likely an issue for marine primary productivity despite the fact that it is also an essential element for marine algae. However, the potential toxicity of boron coupled with its high concentration in the ocean, suggest the need for some sort of homeostatic control mechanisms in marine organisms. The control of boron concentrations is a critical issue in the context of seawater desalination (Öztürk et al. 2008). The remarkable observation that a number of marine natural 


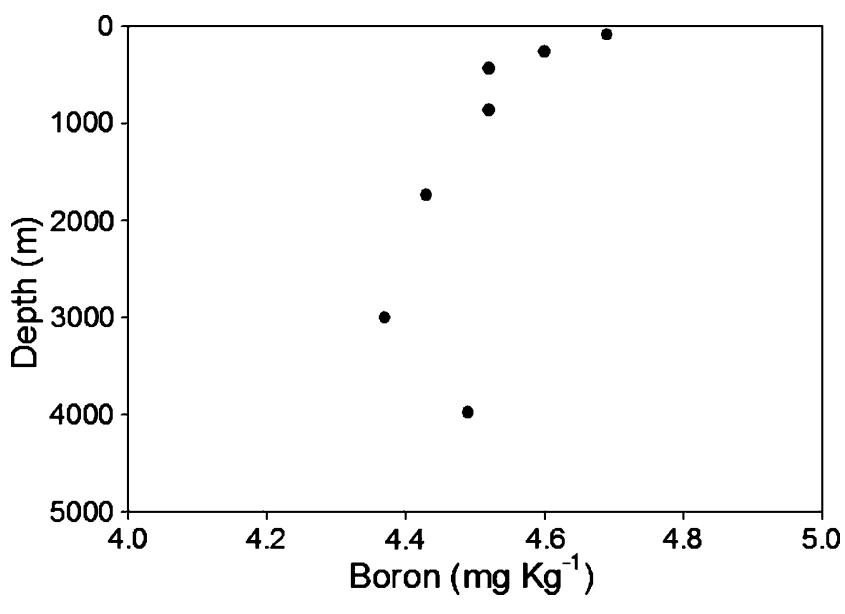

Fig. 1 Representative depth profile of total dissolved boron concentrations at $18^{\circ} 22^{\prime} \mathrm{N}, 165^{\circ} 54^{\prime} \mathrm{W}$ (Uppstrom 1974)

products contain boron suggests that organisms have not only adapted to the presence of high boron concentrations in their environment but have made use of its abundance for a variety of biological uses.

\section{General Introduction to the Chemistry of Boron}

Boron typically exists as trigonal planar $\mathrm{BX}_{3}$ species given its $2 s^{2} 2 p^{1}$ electronic configuration. However, this electrondeficient element often reacts with electron pair donors via its empty $p_{z}$ orbital to produce formally dative bonded tetrahedral "adducts". Thus, trigonal planar boric acid is the primary soluble form of boron in natural waters. As a very weak acid, with a $\mathrm{p} K_{\mathrm{a}}$ of 9.15 , boric acid and the sodium borates exist predominantly as undissociated boric acid [B $\left.(\mathrm{OH})_{3}\right]$ in dilute aqueous solution below $\mathrm{pH}$ 7. Above $\mathrm{pH} 10$, the tetrahedral metaborate anion $\mathrm{B}(\mathrm{OH})_{4}{ }^{-}$becomes the main species in solution. Consequently, since at least the $1940 \mathrm{~s}, \mathrm{~B}(\mathrm{OH})_{3}$ and $\mathrm{B}(\mathrm{OH})_{4}{ }^{-}$have been recognized as the primary boron species in seawater (Sverdrup et al. 1942). However, boric acid is not formally a proton donor, but rather reacts with a hydroxyl ion from water to form the $\mathrm{B}(\mathrm{OH})_{4}{ }^{-}$adduct and releases a proton in the process via the reaction:

$\mathrm{B}(\mathrm{OH})_{3}+\mathrm{H}_{2} \mathrm{O} \rightleftarrows \mathrm{B}(\mathrm{OH})_{4}^{-}+\mathrm{H}^{+}$

At high boron concentrations $(>0.025 \mathrm{M})$ between $\mathrm{pH} 6$ and 11, highly water soluble polyborate ions such as $\mathrm{B}_{3} \mathrm{O}_{3}(\mathrm{OH})_{4}{ }^{-1}, \mathrm{~B}_{4} \mathrm{O}_{5}(\mathrm{OH})_{4}{ }^{-2}$, and $\mathrm{B}_{5} \mathrm{O}_{6}(\mathrm{OH})_{4}{ }^{-1}$ form, but such concentrations are almost never observed in the environment and hence these species are of little importance biologically.

In seawater, inorganic boron content generally bears a linear relationship to chloride content. A ratio of $0.00024 \mathrm{~g}$ boron/g of total halogen expressed as chloride ion has been calculated (UNEP 1998) with dissolved species comprised largely of partially dissociated boric acid along with weakly associated ion-pairs of neutral and positively charged borate complexes of sodium, magnesium, and calcium. Noakes and Hood (1961) concluded that organic-bound boron contributes very little to the total boron content of seawater, but that boron associated with organic matter covaried with dissolved oxygen content, with the lowest concentrations found in oxygen minimum zones.

Although the reaction chemistry of boron can be complex with a myriad of theoretically and technologically important known boron hydrides and carboranes, the only biologically relevant reactions of likely importance in the mildly basic aqueous milieu of seawater are those with nitrogen and oxygen donors. The reaction of boric acid/ borate with hydroxyl donors such as alcohols, phenols, diols, polyols, or polysaccharides to produce alkoxides or "boroesters" constitute the most important of these reactions. Indeed, the essentiality of boron for plants likely derives from the reaction of borate with carbohydrates that promotes the cross-linking and stabilization of the plant cell wall (see below). Both mono- and diesters are possible and these are most stable when derived from "chelating" dihydroxy species. The monoesters maintain a trigonal planar configuration with no net charge, while the more important diesters form spirocyclic compounds that are anionic and tetrahedral in geometry.
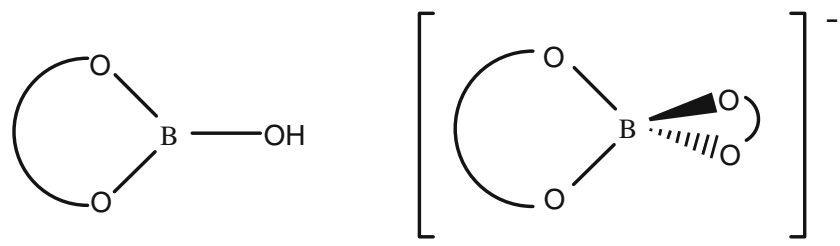

Since water is a product of these "esterifications," decreasing the activity of the solution (i.e. reaction in a less polar environment) will strongly drive the reaction toward the product. However, even in aqueous solutions, the equilibrium constants of such "esterifications" are often sufficiently large to allow significant product formation (Hunt 2001). While 1,3 diols with six-membered chelate ring structures should be preferred on steric grounds to the more ring-strained 1,2 diols with five-membered chelate ring structures, the latter is favored energetically and is the mode most frequently observed (Rietjens and Steenbergen 2005). Also important is the relative $\mathrm{p} K_{\mathrm{a}}$ of the reacting alcohol or phenolic species. Typically, the more acidic the alcohol, the lower the $\mathrm{pH}$ that significant complexation occurs. At higher $\mathrm{pH}$, competition with hydroxide ion to form borate becomes important.

Considerable controversy has arisen as to whether the reactive boron species in these reactions is boric acid or 
borate. Initially, since such reactions with alcohols occur primarily at alkaline $\mathrm{pH}$, the reactive boron species was assumed to be borate, which predominates at high $\mathrm{pH}$ (Fig. 3a). However, recent work has shown unequivocally that this view is incorrect and that the reactive species even in alkaline $\mathrm{pH}$ is in fact boric acid (Bishop et al. 2004; Rietjens and Steenbergen 2005).

\section{Analytical Methods}

Boron is a surprisingly difficult element to measure at the trace concentrations (i.e., $<100 \mu \mathrm{g} / \mathrm{L}$ or $<9.2 \mu \mathrm{M}$ ) expected to be important in biological studies. Problems include: (1) a lack of certified reference materials for inter-laboratory comparisons and validation; (2) sample collection, storage, and preparation issues; and (3) analysis concerns including severe "memory effects" and potential losses or contamination due to volatilization and surface adsorption (Downing et al. 1998). Obviously, the presence of boron in common borosilicate glasses precludes their use during sample collection and preparation, but more insidious is the presence of glass components in analytical instrumentation. The preparation of boron-free water for analytical purposes also requires special attention (Kano and Darbouret 1999). If concentrations of interest are relatively high and more sophisticated instrumentation is unavailable, a number of optical and or fluorescence methods are available for the determination of boron (UNEP 1998). However, the analytical methods of choice are inductively coupled plasma atomic emission spectroscopy (ICP-AES) and inductively coupled plasma mass spectrometry (ICP-MS), which are relatively fast, require small sample volumes, are subject to minimal spectral or mass interferences, and applicable to a wide variety of sample types. ICP-AES has detection limits on the order of $0.5 \mathrm{mg} / \mathrm{L}(0.05 \mathrm{mM})$, whereas ICP-MS has detection limits on the order of $1 \mu \mathrm{g} / \mathrm{L}$
$(0.09 \mu \mathrm{M})$ and the added advantage of determining the stable isotope ratios of ${ }^{10} \mathrm{~B} /{ }^{11} \mathrm{~B}$ (Lécuyer et al. 2002). Stable isotope ratios can also be measured by ion microprobe or thermoionization mass spectrometry (TIMS, Spivack and Edmond 1986; Chaussidon and Albarède 1992). Such stable isotope ratios can be particularly valuable for biological tracer, biogeochemical cycling, and paleoclimate studies (see below) given the absence of radioactive boron isotopes and ready availability of various isotopically pure ${ }^{10}$ B-bearing compounds.

Given sufficient materials and boron concentrations, ${ }^{11} \mathrm{~B}$ boron nuclear magnetic resonance (NMR) is a method that provides structural information as well as quantitative determination. This technique has been used extensively in laboratory studies to provide unparalleled information (Chuda et al. 1997); unfortunately, natural materials frequently do not contain sufficiently high concentrations.

\section{Marine and Geochemistry of Boron}

\section{Biogeochemical Cycle from an Ocean Perspective}

Like most elements, boron is cycled through the atmosphere, hydrosphere, lithosphere, and biosphere by a variety of processes. Park and Schlesinger (2002) provide a quantitative literature review of this global biogeochemical cycle; here we focus on fluxes into and out of the ocean (Fig. 2), the largest surficial boron reservoir at $\sim 6.2 \times 10^{6} \mathrm{Tg}$ (Harriss 1969). Oceanic boron fluxes are dominated by exchanges with the atmosphere; with outflux largely through seawater aerosol production and influx through direct precipitation, direct dry deposition, and gaseous absorption. The hydrosphere is the next largest flux to the ocean through riverine delivery of boron from natural (i.e., atmospherically delivered and weathering produced) and anthropogenic (e.g., soap, fertilizer, fire retardant) sources,
Fig. 2 Boron influxes and outfluxes for the global ocean in $\mathrm{Tg}$ year-1 (based on estimates from Park and Schlesinger 2002)

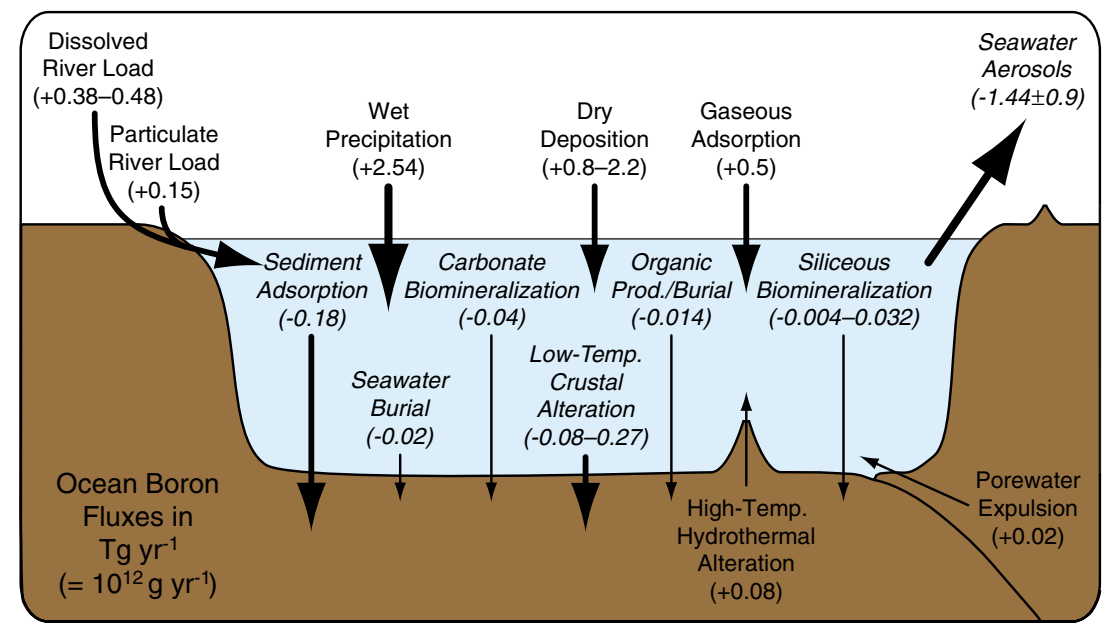


with the latter having approximately doubled from prehistoric times through active mining and widespread societal applications.

Though small compared to the above, fluxes among the lithosphere and ocean are arguably the most complex: lithosphere-to-ocean fluxes include hydrothermal venting at divergent plate boundaries (i.e., oceanic ridges where new crust is produced) and sedimentary porewater expulsion at convergent plate boundaries (i.e., oceanic trenches where crust and overlying sediments are subducted). Ocean-tolithosphere fluxes include adsorption onto sediments (particularly clay minerals), burial of seawater (i.e., porewater), and seawater-driven alteration of oceanic crust at low temperatures (i.e., away from divergent plate boundaries). Finally, the biosphere transfers dissolved boron into organic matter, which is largely oxidized in the water column with little burial, as well as calcitic and siliceous skeletons that contribute to marine sediments.

Based on the above processes, the estimated boron influx to the global ocean is 4.47-5.97 $\mathrm{Tg} \mathrm{year}^{-1}$ and the boron outflux from the global ocean as $0.86-2.88 \mathrm{Tg}$ year $^{-1}$. Park and Schlesinger (2002) attribute this major imbalance to a relatively poorly constrained atmospheric budget (cf. recent work by Rose-Koga et al. 2006; Xiao et al. 2007); exclusion of this atmospheric component produces a relatively balanced boron budget for the ocean (i.e., influx of $0.63-0.73$ versus outflux of $0.32-0.87$ ). In addition to elemental fluxes, boron stable isotopic variations (i.e., $\delta^{11} \mathrm{~B}$; see next section) within and among these reservoirs provide additional constraints on the ocean boron budget, though these largely ignore the atmosphere given their geoscience focus (e.g. Seyfried et al. 1984; Spivack et al. 1987; You et al. 1993; Wunder et al. 2005).

Biomineralization and Boron Isotopes as a Paleo-pH Proxy

Modern seawater averages $\sim 39.5 \%$ in its $\delta^{11} \mathrm{~B}$ as expressed in standard delta notation measured relative to NBS SRM957 (IUPAC 1998). Ambient $\mathrm{pH}$ controls the speciation of this dissolved boron among largely $\mathrm{B}(\mathrm{OH})_{3}$ and $\mathrm{B}(\mathrm{OH})_{4}$ (Fig. 2a; Dickson 1990; DOE 1994) as well as the $\delta^{11} \mathrm{~B}$ of these species through coordination-based differences in vibrational energy, with trigonal $\mathrm{B}(\mathrm{OH})_{3}$ enriched in ${ }^{11} \mathrm{~B}$ relative to tetrahedral $\mathrm{B}(\mathrm{OH})_{4}$ (Fig. 2b; Zeebe 2005). Theoretic estimates of thermodynamic equilibrium fractionation factors $(\alpha)$ for this $\mathrm{B}(\mathrm{OH})_{3}-\mathrm{B}(\mathrm{OH})_{4}$ system range between 1.0176 to 1.030 at $300 \mathrm{~K}$ (i.e., enrichment factors $(\varepsilon)$ of $18-30 \%$ for $\mathrm{B}(\mathrm{OH})_{4}$ at $25^{\circ} \mathrm{C}$ for typical seawater; Fig. 3b, gray curves), with some recent theoretical estimates of 1.026-1.030 (Oi et al. 2000; Liu and Tossel 2005; Zeebe 2005) that are comparable to recent abiotic experimental values of 1.0285 and 1.0272 (Byrne et al. 2006; Klochko et al. 2006, respectively).
Based on these boron- $\mathrm{pH}$ relationships, paleoceanographers have aggressively sought to understand the thermodynamics and kinetics of boron elemental and isotopic systematics in order to infer past ocean $\mathrm{pH}$ from the $\delta^{11} \mathrm{~B}$ of lattice-bound $\mathrm{B}(\mathrm{OH})_{4}$ in the carbonate skeletons of marine organisms (e.g. Hemming and Hanson 1992; Spivack et al. 1993; Sanyal et al. 1995; Pearson and Palmer 2000; Hönish and Hemming 2005; Hemming and Hönisch 2007; Zeebe et al. 2009). The combination of such a "paleo-pH" proxy with another concentration-based parameter of the marine carbonate system, such as $\left[\mathrm{CO}_{3}{ }^{2-}\right], \sum \mathrm{CO}_{2}$, or total alkalinity, provides critical constraints on the history of carbonate equilibria, which in turn modulates paleoatmo-
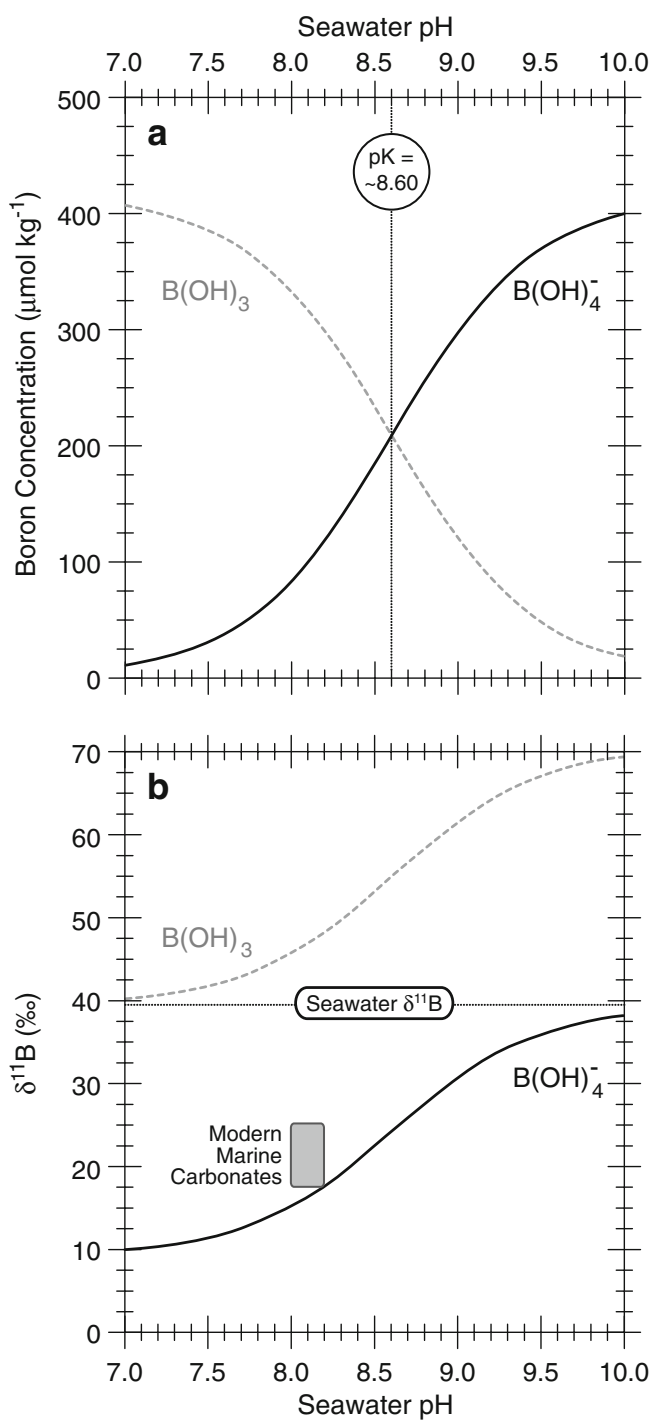

Fig. 3 Elemental and isotopic principles underlying the $\delta^{11} \mathrm{~B}$ paleo$\mathrm{pH}$ proxy. a The concentration of dissolved boron species as a function of $\mathrm{pH}$ at $T=25^{\circ} \mathrm{C}, S=35$, and total boron concentration= $416 \mu \mathrm{mol} \mathrm{kg}{ }^{-1}(\sim 405 \mu \mathrm{M})$ (DOE 1994) with estimated $\mathrm{p} K$ value for boron (Dickson 1990). b Predicted $\delta^{11} \mathrm{~B}$ of $\mathrm{B}(\mathrm{OH})_{3}$ and $\mathrm{B}(\mathrm{OH})_{4}$ as a function of seawater $\mathrm{pH}$ assuming a fractionation factor of 1.030 (Zeebe et al. 2008) 
spheric $\mathrm{pCO}_{2}$, a major parameter in global climate history and dynamics. Given uncertainties in fractionation factors and potential effects of biomineralization, many researchers have pursued a naturalistic approach of culturing planktonic foraminifera and scleractinian corals over a range of $\mathrm{pH}$ values to produce species-specific $\delta^{11} \mathrm{~B}-\mathrm{pH}$ calibrations (Fig. 4; various symbols and curves). These calibrations show offset but congruent relationships and are also more congruent with fractionation factors that are smaller (i.e., 1.018 and 1.020) than those predicted by most recent theoretical and experimental work.

Based on the above relationships, Zeebe et al. (2009) note that (1) regardless of the true fractionation factor for the seawater $\mathrm{B}(\mathrm{OH})_{3}-\mathrm{B}(\mathrm{OH})_{4}$ system, $\mathrm{B}(\mathrm{OH})_{4}$ must experience additional isotopic fractionation during biomineralization, otherwise these species-specific data would produce a single curve that would be the $\delta^{11} \mathrm{~B}-\mathrm{pH}$ relationship for $\mathrm{B}(\mathrm{OH})_{4}$ and (2) the $\delta^{11} \mathrm{~B}$ of $\mathrm{B}(\mathrm{OH})_{4}$ cannot be robustly deduced from the $\delta^{11} \mathrm{~B}$ of carbonates and vice versa. In addition, Zeebe (2005) stress that neither these uncertainties in fractionation factors nor these observed differences among speciesspecific calibrations preclude the parallel development and application of species-specific paleo-pH proxies.

An important question for robust application of this paleo-pH proxy is that the $\delta^{11} \mathrm{~B}$ of the oceanic reservoir is constant or independently constrained through time. Firstorder limitations are based largely on estimated oceanic boron residence times, which range widely from $\sim 3$ to $\sim 20$ million years (Spivack and Edmond 1987; Park and

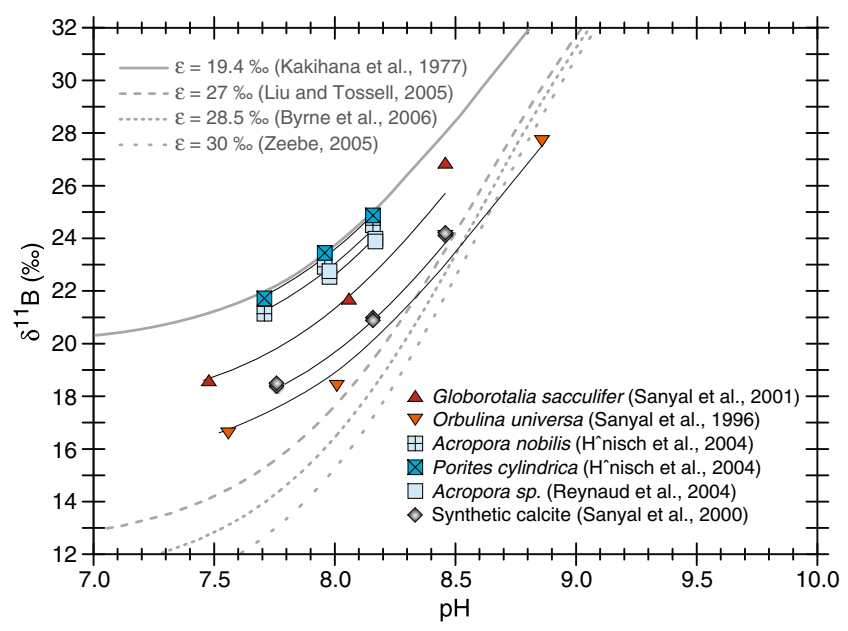

Fig. 4 Comparison of theoretical and empirical relationships between $\mathrm{pH}$ and $\delta^{11} \mathrm{~B}$. Gray curves represent various theoretical fractionation factors $(\alpha)$ that produce various enrichment factors $(\varepsilon)$. Symbols and associated black curves represent species-specific culturing data for calcitic planktonic foraminifera (i.e., Globorotalia sacculifer, Orbulina universa), aragonitic scleractinian corals (i.e., Acropora, Porites), and synthetic calcite. Error bars $( \pm 1$ s) omitted for clarity; $\mathrm{pH}$ uncertainty typically $\pm 0.1 \mathrm{U}$ and temperature uncertainty typically better than $\pm 0.75^{\circ} \mathrm{C}$ (modified from Hemming and Hönisch 2007 and Zeebe et al. 2008)
Schlesinger 2002, respectively). Geochemical studies support relatively stable oceanic $\delta^{11} \mathrm{~B}$ for the last $\sim 10$ million years, but geochemical modeling suggests that seawater $\delta^{11} \mathrm{~B}$ has varied over a range of $6-10 \%$ over the past 60 to 120 million years, which could account for observed $\delta^{11} \mathrm{~B}$ variations in many paleo-pH studies (Lemarchand et al. 2000; Simon et al. 2006). The need to constrain oceanic variation in $\delta^{11} \mathrm{~B}$ remains an important issue for application of the paleo-pH proxy in deeper time as independent geologic evidence supports significant secular variations in ocean pH (e.g. Royer et al. 2001).

\section{Boron as a Nutrient of Marine Algae}

While a number of studies report that boron is essential for the growth and development of marine algae, the specific role(s) of the element remain unclear. Boron was recognized as an essential nutrient for terrestrial plants since the 1920s (Warington 1923), whereas symptoms of boron toxicity have been reported for soil concentrations $>1 \mathrm{ppm}$ (e.g. Yau et al. 1995).

Pioneering studies in the 1940s and 1950s reported that boron is essential for different groups of algae and cyanobacteria. For example, in the marine red algae Bangia and Porphyra, boron at seawater concentrations is essential for sustained growth (Henkel 1952). The freshwater green alga Chlorella has a similar boron requirement for growth (McIlrath and Skok 1958), whereas boron deficiency in the cyanobacterium Nostoc leads to chlorosis (Eyster 1952). Consequently, boron has been recognized as an important constituent of algal culture media (Spector 1956). Lewin demonstrated the requirement of boron for the growth of marine pennate and centric diatoms (Lewin 1965; Lewin 1966a; Lewin 1966b; Lewin and Chen 1976), with cell division being much reduced at boron concentrations less than $0.5 \mathrm{mg} \mathrm{L}^{-1}(\sim 0.05 \mathrm{mM}$; i.e. $\sim 10 \%$ natural seawater concentration) and ceasing completely at lower concentrations (Lewin 1966a). Under boron-deficient conditions, the content of phenolic compounds in the diatom Cylondrotheca fusiformis is more than doubled, while the majority of other major cell constituents remain unchanged (Lewin and Chen 1976). Shortly after these diatom-based studies, the essential role of boron for the development of Fucus edentatus Pyl. (Phaeophyceae) was also recognized (McLachlan 1977): omission of boron from the culture medium resulted in moribund embryos, but normal development could be restored by adding 1-4 $\mu \mathrm{M}$ boron. Gametogenesis in brown algal gametophytes (of the kelps Laminaria japonica and Laminaria angustata and of the sulfuric acid-producing Desmarestia ligulata) is strongly affected by the availability of boron and iron which show partially antagonistic effects, with high boron concentra- 
tions acting inhibitory which can be alleviated by $\mathrm{Fe}^{3+}$ supplements (Motomura and Sakai 1984). The partially antagonistic interplay between iron and boron is particularly striking in light of the more recent findings that $\mathrm{Fe}^{3+}$ and borate compete for binding to microbial siderophores (Amin et al. 2007; Harris et al. 2007), even though no functional link between the two effects has been established yet.

Little is known about the boron content of marine algae and more research is definitely needed regarding this aspect. Öy (as quoted by Black and Mitchell 1952) published some figures for minor elements in the brown algae Ascophyllum nodosum, Laminaria sp., Fucus serratus and Fucus vesiculosus, with boron concentrations typically in the range of $100 \mathrm{ppm}$. Since this concentration is higher than that of the seawater, this implies that there must be some sort of active uptake and homeostatic control mechanism in place in these organisms.

The role of boron in higher plants including boron uptake and molecular aspects of boron transporters has been reviewed recently (Tanaka and Fujiwara 2008), with a major function being the cross-linking of pectins for the maintenance of cell wall integrity (Kobayashi et al. 1996). In general, borate reacts most strongly with sugars that have cis-diols on a furanoid ring as a result of both steric and electronic forces. Therefore, compounds bearing cis-diols on a furanose ring form far stronger complexes with borate than those on a pyranoid ring such as the more common alpha-D-glucose. This affinity is reflected in the differing equilibrium constants $\left(\sim 10^{3}\right.$ for glucose vs. $\sim 10^{7}$ for ribose) (Hunt 2001). In fact, only two natural sugars have the strongly boron-binding cis-diol functionality on a furanose ring, ribose and apiose. It was found that the essentiality of boron to higher plants stems from its ability to crosslink cell wall carbohydrates, Therefore, it is not surprising that the first isolated B-polysaccharide was identified as a complex of the peptic polysaccharide rhamnogalacturonan II (RG-II) (Matoh and Kobayashi 2001). RG-II is notable in that it has the richest known diversity of sugars and linkages. Monomeric RG-II has four side chains, two of which contain apiose. The apiosyl residues are engaged in B-binding and borate crosslinks between apiofuranosyl residues of two 2-O-methyl-D-xylose sidechains resulting in a dimeric complex between two molecules of monomeric RG-II and one borate. The presence of boron crosslinks in marine plants was initially described for the sulfated polysaccharide of the green seaweed Ulva lactuca (Haug 1976) and has been confirmed for red, green, and brown macroalgae by ${ }^{11} \mathrm{~B}$ NMR analysis (Chuda et al. 1997). Even though it is tempting to speculate that boron may play a key role for the cell wall integrity of marine algae, substantial further research clearly is needed for a better understanding of the biological significance of the boron requirement by marine algae.

\section{Boron Transport and Regulation}

A broad systematic understanding of boron uptake mechanisms is lacking for animals, though uptake is known to occur across mucous membranes of the gastrointestinal and respiratory systems. In contrast, higher plants are fairly well studied with regards to boron uptake (Tanaka and Fujiwara 2008). Boric acid is an uncharged and undissociated molecule over much of the physiological $\mathrm{pH}$ range and is therefore considered to be the species taken up (Raven 1980). Boron uptake was largely assumed to occur through passive diffusion, but recent studies over the last decade have shown that uptake occurs as an active process mediated by active BOR transporters or facilitated by nodulin-like intrinsic proteins (NIPs). BOR1, a member of the SLC4 anion-exchanger superfamily (Frommer and Von Wiren 2002) which also includes bicarbonate transporters, was identified as the first transport protein involved in active xylem loading in the higher plant model Arabidopsis (Takano et al. 2002). Shortly afterwards, the same group found a member of the major intrinsic proteins, namely NIP $5 ; 1$, to be essential for boron uptake and plant development under boron limitation (Takano et al. 2006).

Homologs, clustering in the same clade with BOR1, the yeast protein YNL275w (BOR1p) and the BTR1 protein of humans, are found in the genomes of the diatoms Thalassiosira pseudonana, Phaeodactylum tricornutum, and the brown seaweed Ectocarpus siliculosus (Fig. 5). This

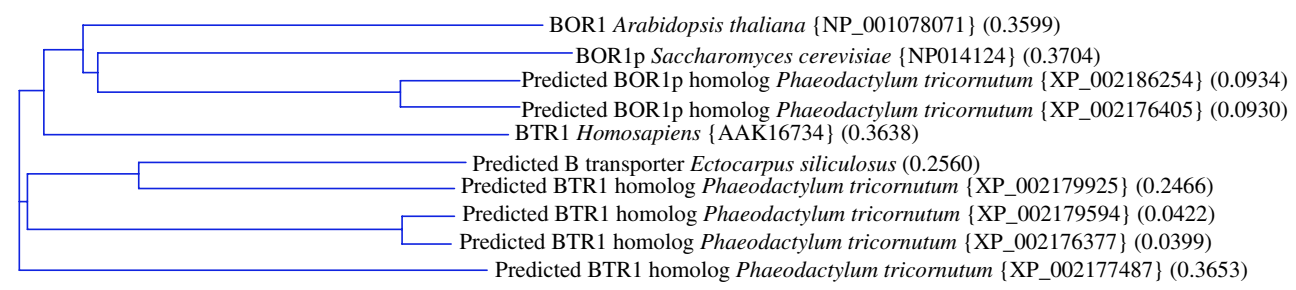

Fig. 5 Phylogenetic analysis of putative bicarbonate/borate transporters sequences. Tree generation was done using VectorNTI (Invitrogen) based on three known borate transporters (BOR1, BOR1p, and BTR1).
Nucleotide database accession numbers are provided in brackets and distances are in parentheses 


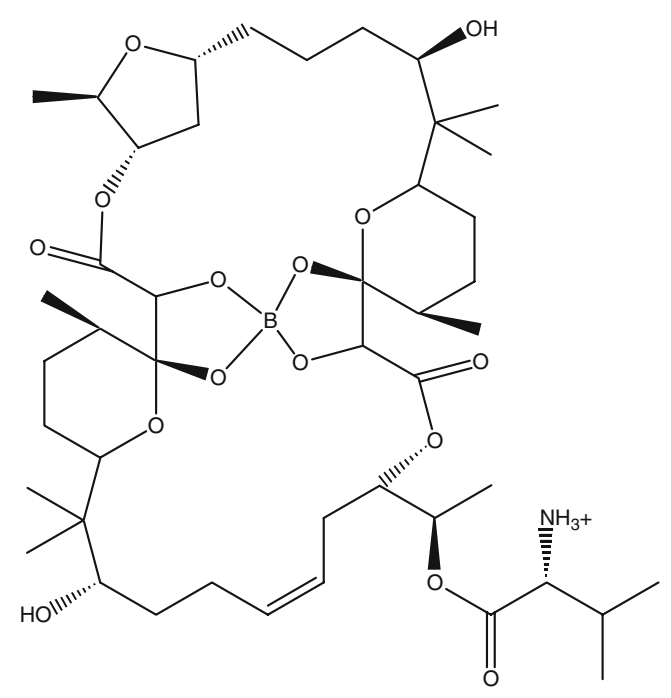

Fig. 6 The streptomycete-derived antibiotic boromycin

observation suggests that boron transport and regulation is widespread among marine plants.

However, because of the similarities between the purported borate transporters and their bicarbonate analogs, detailed biochemical studies will be needed to confirm the physiological function/substrates of these gene products.

\section{Boron-containing Natural Products from Marine Prokaryotes}

Considering the abundance of boron in the Earth's crust and ocean, it is surprising how few boron-containing natural products are known-however, it is similarly striking that only one of them is of terrestrial origin with all others coming from marine microorganisms. All boron natural products known to date are prokaryotic metabolites. An obvious, intriguing question for further research is whether eukaryotes use boron in a similar manner in their metabolism and whether they produce any boron-containing natural products.

The first identified boron-containing natural product was boromycin (Fig. 6; Hütter et al. 1967; Dunitz et al. 1971; Marsh et al. 1974), which was isolated from a culture of Streptomyces antibioticus ETH 28829 that originated from a terrestrial soil sample from the Ivory Coast. The second boron natural product, the macrodiolide antibiotic aplasmomycin, was found in the related, but marine Streptomyces griseus (Okami et al. 1976). The biosynthesis of this unusual compound has been elucidated (Chen et al. 1979).

The next high-profile natural product was the quorum sensing molecule autoinducer-2 (AI-2), which was first isolated from the bioluminescent marine bacterium Vibrio harveyi (Chen et al. 2002). In fact, its production by a range of other bacteria is remarkable and AI- 2 has been postulated to function in inter-species communication (Miller and Bassler 2001). However, recently it was discovered that the active form of AI-2 found in terrestrial bacteria such as Salmonella typhimurium does not contain boron but rather it is simply the furanose sugar itself. This finding was confirmed by the crystal structures of the two molecules bound to their respective receptors, which shows unequivocally that boron is bound to the AI-2 of marine bacteria but not to the AI-2 of terrestrial bacteria (Miller et al. 2004, Fig. 7). This is a powerful example of how marine organisms have had to adapt to the high concentrations of boron in their environment or vice versa.

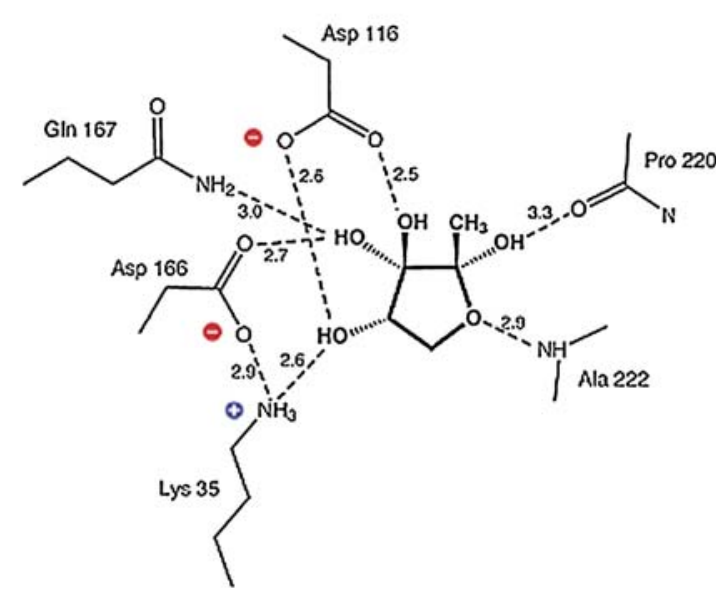

Fig. 7 A comparison of the binding of the AI-2 signal molecule, 2methyl-2,3,3,4-tetrahydroxytetrahydrofuran (R-THMF) to the binding site in its receptor, LsrB, from S. typhimurium (left) with that in the

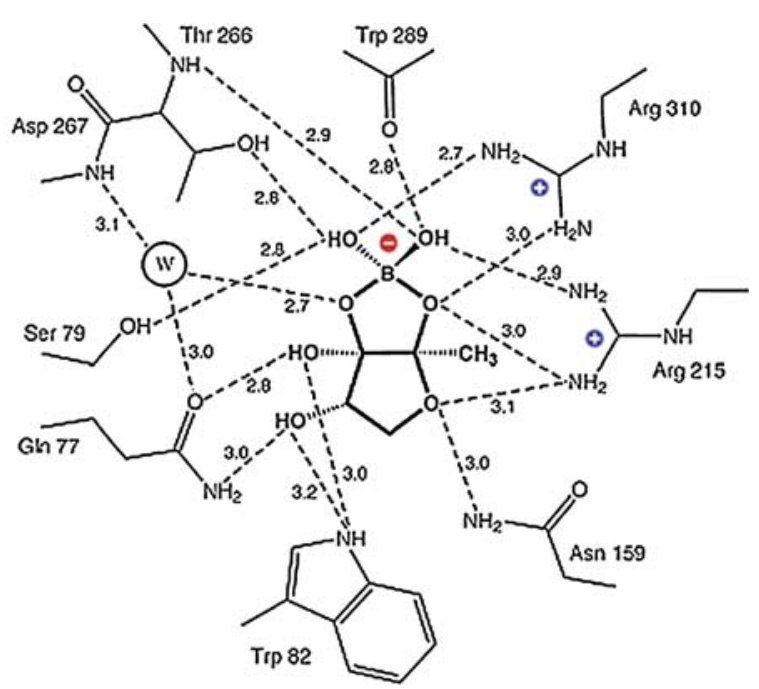

corresponding LuxP receptor from $V$. harveyi (right). Note the presence of boron only in the latter 
Most recently, we became interested in boron-binding siderophores $\left(\mathrm{Fe}^{3+}\right.$ chelators) of marine bacteria. The first such case was a surprise finding of a compound similar to the known siderophore vibrioferrin produced in parallel to this chelator by cultures of a Marinobacter sp. (strain DG 893) (Amin et al. 2007). Borate occurring either naturally in seawater or in the borosilicate glass of the used flasks competed with $\mathrm{Fe}^{3+}$ for binding to these ligands. A more systematic investigation subsequently revealed that a number of siderophores, such as rhizoferrin and petrobactin, share this hitherto unrecognized property with vibrioferrin, with the relevant functionality being the availability of a vicinal dianionic oxygen containing binding group (i.e., citrate or catecholate) in the siderophore backbone (Harris et al. 2007). In contrast, hydroxamate siderophores, such as aerobactin, which lack this functional group, do not bind boron (Harris et al. 2007). The biological significance of this feature remains at the moment unknown, but considering the abundance of boron in the ocean and the importance of siderophores to marine microbial trace element acquisition it is likely to be very relevant. One attractive hypothesis is that while siderophores are known to have as their primary function the binding and transport of iron from the environment into microbial cells, increasing evidence suggests that they may also play another significant role as signaling or "quorum sensing" molecules. The observed affinity of certain siderophores for borate allows for significant concentrations of Bsiderophores to exist even at oceanic $\mathrm{pH}$. These concentrations, although small, could well be sufficient for them to function as signaling molecules as with AI-2. Binding of the tetrahedral boron to these siderophores will also result in a conformation that would be different from either the free siderophore or its iron complex, allowing a distinction to be made between its iron uptake and any cell signaling roles. This area is ripe for further experimentation.

\section{Conclusions and Outlook}

Findings in several disciplines suggest that boron, an abundant element in the ocean, is involved in a range of aspects of marine life and it is considered an essential trace element. While all boron-containing and boron-binding low-molecular weight metabolites are of prokaryotic origin, boron also plays an important role in stabilizing plant and algal cell walls by cross-linking carbohydrates. The molecular biology of boron transporters in different branches of the tree of life is beginning to emerge, but the knowledge remains far from phylogenetically representative at the current time. Studies in biological oceanography investigating the correlation of boron with phytoplankton abundance (in particular, whether boron in seawater is drawn down in algal blooms) would appear very timely. Also, the potential occurrence of low-molecular weight, boroncontaining compounds in eukaryotes and much of the other remaining physiological roles of this element remain largely enigmatic at this stage and require significant, further research effort.

We would like to close by highlighting a number of biotechnology-related perspectives. The central role of boron in quorum sensing of marine bacteria opens perspectives for the control of bacterial biofilms both on man-made surfaces in the sea and in a wider context. The involvement of boron in cell wall stability has potential implications for the resistance of plants and algae to infection, for the technical extractability of cell contents and for the texture of edible seaweeds. In the latter context, it is unknown whether the boron content of seaweeds and seafood is beneficial or problematic from a nutritional standpoint and definitely requires further study.

Overall, one can conclude that the current state of knowledge has opened some intriguing perspectives for further fundamental and applied research about the role of this enigmatic bioelement.

Acknowledgments We are most grateful to Elsa Atson (Chemical Heritage Foundation, Philadelphia, PA, USA) and Guillaume Tcherkez (Université de Paris-Sud XI-Orsay, France) for their support in tracing and obtaining historic literature sources, to J. Mark Cock (CNRSUPMC Station Biologique de Roscoff, France) for access to the unpublished Ectocarpus genome sequence, and to Bärbel Hönisch (Lamont-Doherty Earth Observatory) for providing compilations of theoretical and empirical $\delta^{11} \mathrm{~B}$ data. This work was supported in part by NOAA Grant \#NA04OAR4170038, California Sea Grant College Program Project \#020-C-N, through the NOAA National Sea Grant College Program, U.S. Department of Commerce. The statements, findings, conclusions and recommendations are those of the author(s) and do not necessarily reflect the views of California Sea Grant or the U.S. Department of Commerce.

Open Access This article is distributed under the terms of the Creative Commons Attribution Noncommercial License which permits any noncommercial use, distribution, and reproduction in any medium, provided the original author(s) and source are credited.

\section{References}

Amin SA, Küpper FC, Green DH, Harris WR, Carrano CJ (2007) Boron binding by a siderophore isolated from marine bacteria associated with the toxic dinoflagellate Gymnodinium catenatum. J Am Chem Soc 129:478-479

Bishop M, Shahid N, Yang JZ, Barron AR (2004) Determination of the mode and efficacy of the cross-linking of guar by borate using MAS B-11 NMR of borate cross-linked guar in combination with solution B-11 NMR of model systems. Dalton Transactions: $2621-2634$

Black WAP, Mitchell RL (1952) Trace elements in the common brown algae and in sea water. J Mar Biol Assoc UK 30:575-584

Byrne RH, Yao W, Klochko K, Tossell JA, Kaufman AJ (2006) Experimental evaluation of the isotopic exchange equilibrium 
${ }^{10} \mathrm{~B}(\mathrm{OH})_{3}+{ }^{11} \mathrm{~B}(\mathrm{OH})_{4}{ }^{-}={ }^{11} \mathrm{~B}(\mathrm{OH})_{3}+{ }^{10} \mathrm{~B}(\mathrm{OH})_{4}{ }^{-}$in aqueous solutions. Deep-Sea Res I 53:684-688

Chaussidon M, Albarède F (1992) Secular boron isotope in the continental crust: an ion microprobe study. Earth Planet Sci Lett 108:229-241

Chen TSS, Chang C, Floss HG (1979) Biosynthesis of the boroncontaining macrodiolide antibiotic aplasmomycin. J Am Chem Soc 101:5826-5827

Chen X, Schauder S, Potier N, Van Dorsselaer A, Pelczer I, Bassler BL, Hughson FM (2002) Structural identification of a bacterial quorum-sensing signal containing boron. Nature 415:545-549

Chuda Y, Ohnishi-Kameyama M, Nagata T (1997) Identification of the forms of boron in seaweed by ${ }^{11} \mathrm{~B}$ NMR. Phytochemistry 46:209-213

Davy H (1808) Electro-chemical researches, on the decomposition of the earths; with observations on the metals obtained from the alkaline rarths, and on the amalgamprocured from ammonia. Phil Trans Roy Soc London 98:333-370

Dickson AG (1990) Thermodynamics of the dissociation of boric acid in synthetic seawater from 273.15 to $318.15 \mathrm{~K}$. Deep-Sea Res 37:755-766

DOE (1994) Handbook or Methods for the Analysis of the Various Parameters for the Carbon Dioxide System in Sea Water (Version 2). Oak Ridge National Laboratory

Downing RG, Strong PL, Hovanec BM, Northington J (1998) Considerations in the determination of boron at low concentrations. Biol Trace Elem Res 66:3-21

Dunitz JD, Hawley DM, Miklos D, White DNJ, Berlin Y, Marusic R, Prelog V (1971) Metabolic products of microorganisms. 95. Structure of boromycin. Helvetica Chimica Acta 54: 1709-\&

Eyster C (1952) Necessity of boron for Nostoc muscorum. Nature 170:755

Frommer WB, Von Wiren N (2002) Ping-pong with boron. Nature 410:282-283

Gay-Lussac J-L, Thenard L-J (1808) Sur la décomposition et la recomposition de l'acide boracique. Ann Chim Phys (Paris) 68:167-174

Goldbach HE, Rerkasem B, Wimmer MA, Brown PH, Thellier M, Bell RW (2001) Boron in plant and animal nutrition. Kluwer Academic/Plenum, New York

Harriss RC (1969) Boron regulation in the oceans. Nature 223:290291

Harris WR, Amin SA, Küpper FC, Green DH, Carrano CJ (2007) Borate binding to siderophores: structure and stability. J Am Chem Soc 129:12263-12271

Haug A (1976) The influence of borate and calcium on the gel formation of a sulfated polysaccharide from Ulva lactuca. Acta Chemica Scandinavica B 30:562-566

Hemming NG, Hanson GN (1992) Boron isotopic composition and concentration in modern marine carbonates. Geochim Cosmochim Acta 56:537-543

Hemming NG, Hönisch B (2007) Boron isotopes in marine carbonate sediments and the $\mathrm{pH}$ of the ocean. IN Proxies in Late Cenozoic Paleoceanography. In: Hillaire-Marcel C, de Vernal A (eds) Proxies in Late Cenozoic Paleoceanography. Elsevier, pp 717-734

Henkel R (1952) Ernährungsphysiologische Untersuchungen an Meeresalgen, insbesondere an Bangia pumila. Kiel Meeresforsch 8:192-211

Hönish B, Hemming NG (2005) Surface ocean pH response to variations in $\mathrm{pCO}_{2}$ through two full glacial cycles. Earth Planet Sci Lett 236:305-314

Hunt CD (2001). In: Goldbach HE, Rerkasem B, Wimmer MA, Brown PH, Thellier M, Bell RW (eds) Boron in Plant and Animal Nutrition. Kluwer Academic/Plenum, New York

Hütter R, Keller-Schierlein W, Knüsel F, Prelog V, Rodgers GC Jr, Suter P, Vogel G, Voser W, Zähner H (1967) 159. Stoffwechsel- produkte von Mikroorganismen. 57. Boromycin. Helvetica Chimica Acta 50:158-159

IUPAC (1998) Isotopic composition of the elements 1997. Pure Appl Chem 70:217-235

Kano I, Darbouret D (1999) Ultrapure Water for Boron and Silica Sensitive Laboratory Applications. Millipore Corporation

Klochko K, Kaufman AJ, Yao W, Byrne RH, Tossell JA (2006) Experimental measurement of boron isotope fractionation in seawater. Earth Planet Sci Lett 248:261-270

Kobayashi M, Matoh T, Azuma J (1996) Two chains of rhamnogalacturonan II are cross-linked by borate-diol ester bonds in higher plant cell walls. Plant Physiol 110:1017-1020

Lécuyer C, Grandjean P, Reynard B, Albarède F, Telouk P (2002) ${ }^{11} \mathrm{~B} /{ }^{10} \mathrm{~B}$ analysis of geological materials by ICP-MS Plasma 54 : application to the boron fractionation between brachiopod calcite and seawater. Chem Geol 185:45-55

Lemarchand D, Gailardet J, Lewin É, Allègre CJ (2000) The influence of rivers on marine boron isotopes and implications for reconstructing past ocean $\mathrm{pH}$. Nature 408:951-954

Lewin J (1966a) Boron as a growth requirement for diatoms. J Phycol $2: 160-163$

Lewin JC (1966b) Physiological studies of the boron requirement of the diatom, Cylindrotheca fusiformis Reimann and Lewin. J Exp Bot 17:473-479

Lewin JC (1965) The boron requirement of a marine diatom. Naturwissenschaften 52:70

Lewin J, Chen C (1976) Effects of boron deficiency on the chemical composition of a marine diatom. J Exp Bot 27:916-921

Liu Y, Tossel JA (2005) Ab initio molecular orbital calculations for boron isotope fractionations on boric acids and borates. Geochim Cosmochim Acta 69:3995-4006

Marsh W, Dunitz JD, White DNJ (1974) Structure of a boron-free hydrolysis product from boromycin. Helvetica Chimica Acta 57:10-17

Matoh T, Kobayashi M (2001). In: Goldbach HE, Rerkasem B, Wimmer MA, Brown PH, Thellier M, Bell RW (eds) Boron in Plant and Animal Nutrition. Kluwer Academic/Plenum, New York

McIlrath WJ, Skok J (1958) Boron requirement of Chlorella vulgaris. Bot Gaz 119:231-233

McLachlan J (1977) Effects of nutrients on growth and development of embryos of Fucus edentatus Pyl. (Phaeophyceae, Fucales). Phycologia 16:329-338

Miller MB, Bassler BL (2001) Quorum sensing in bacteria. Annu Rev Microbiol 55:165-199

Miller ST, Xavier KB, Campagna SR, Taga ME, Semmelhack MF, Bassler BL, Hughson FM (2004) Salmonella typhimurium recognizes a chemically distinct form of the bacterial quorumsensing signal Al-2. Molecular Cell 15:677-687

Motomura T, Sakai Y (1984) Regulation of gametogenesis of Laminaria and Desmarestia (Phaeophyta) by iron and boron. Jap J Phycol (Sorui) 32:209-215

Noakes JE, Hood DW (1961) Boron-boric acid complexes in seawater. Deep-Sea Res 8:121-129

Oi T, Nomura M, Musashi M, Ossaka T, Okomoto M, Kakihana H (2000) Ab initio molecular orbital calculations of reduced partition function ratios for polyboric acids and polyborate anions. Zeitschrift fuer Naturforschung 55:623-628

Okami Y, Okazaki T, Kitahara T, Umezawa H (1976) Studies on marine microorganisms. 5. New antibiotic, aplasmomycin, produced by a streptomycete isolated from shallow sea mud. J Antibiot 29:1019-1025

Öztürk N, Kavak D, Köse TE (2008) Boron removal from aqueous solution by reverse osmosis. Desalination 223:1-9

Park H, Schlesinger WH (2002) Global biogeochemical cycle of boron. Global Biogeochemical Cycles 16: Article no. 1072 
Pearson PN, Palmer MR (2000) Atmospheric carbon dioxide concentrations over the past 60 million years. Nature 406:695-699

Raven JA (1980) Short- and long-distance transport of boric acid in plants. New Phytol 84:231-249

Rietjens M, Steenbergen PA (2005) Crosslinking mechanism of boric acid with diols revisited. Eur J of Inorg Chem 2005:1162-1174

Rose-Koga EF, Sheppard SMF, Chaussidon M, Carignan J (2006) Boron isotopic composition of atmospheric precipitations and liquid-vapour fractionations. Geochim Cosmochim Acta 70:1603-1615

Royer DL, Berner RA, Beerling DJ (2001) Phanerozoic atmospheric $\mathrm{CO}_{2}$ change: evaluating geochemical and paleobiological approaches. Earth-Sci Rev 54:349-392

Sanyal A, Hemming NG, Hanson GN, Broecker WS (1995) Evidence for a higher $\mathrm{pH}$ in the glacial ocean from boron isotopes in foraminifera. Nature 373

Seyfried WE, Janecky DR, Mottl MJ (1984) Alteration fo the oceanic crust: implications for geochemical cycles of lithium and boron. Geochim Cosmochim Acta 48:557-569

Simon L, Lécuyer C, Maréchal C, Coltice N (2006) Modelling the geochemical cycle of boron: implications for the long-term $\delta^{11} \mathrm{~B}$ evolution of seawater and oceanic crust. Chem Geol 225:61-76

Spector WS (1956) Handbook of biological data. W.B. Saunders, Philadelphia

Spivack AJ, Edmond JM (1986) Determination of boron isotope ratios by thermal ionization mass spectrometry of dicesium metaborate cation. Anal Chem 58:31-55

Spivack AJ, Edmond JM (1987) Boron isotope exchange between seawater and the oceanic crust. Geochim Cosmochim Acta 51:1033-1043

Spivack AJ, Palmer MR, Edmond JM (1987) The sedimentary cycle of boron isotopes. Geochim Cosmochim Acta 51:1939-1949

Spivack AJ, You C-F, Smith HJ (1993) Foraminiferal boron isotope ratios as a proxy for surface ocean $\mathrm{pH}$ over the past $21 \mathrm{Myr} .363$ 149-151

Sverdrup HU, Johnson MW, Fleming RH (1942) The Oceans. Their physics, chemistry and general biology. Prentice-Hall, New York
Takano J, Noguchi K, Yasumori M, Kobayashi M, Gajdos Z, Miwa K, Hayashi H, Yoneyama T, Fujiwara T (2002) Arabidopsis boron transporter for xylem loading. Nature 420:337-340

Takano J, Wada M, Ludewig U, Schaaf G, von Wiren N, Fujiwara T (2006) The Arabidopsis major intrinsic protein NIP5;1 is essential for efficient boron uptake and plant development under boron limitation. Plant Cell 18:1498-1509

Tanaka M, Fujiwara T (2008) Physiological roles and transport mechanisms of boron: perspectives from plants. Pflügers ArchivEur J Phys 456:671-677

UNEP (1998) Boron. United Nations Environmental ProgramInternational Programme on Chemical Safety

Uppstrom LR (1974) The boron/chlorinity ratio of deep-sea water from the Pacific Ocean. Deep-Sea Res 21:161-162

Warington K (1923) The effect of boric acid and borax on the broad bean and certain other plants. Annals of Botany 27:629-672

Wunder B, Meixner A, Romer RL, Wirth R, Heinrich W (2005) The geochemical cycle of boron: constraints from boron isotope partitioning experiments between mica and fluid. Lithos 84: 206-216

Xiao YK, Li SZ, Wei HZ, Sun AD, Liu WG, Zhou WJ, Zhao ZQ, Liu CG, Swihart GH (2007) Boron isotopic fractionation during seawater evaporation. Mar Chem 103:382-392

Yau SK, Nachit MM, Hamblin J, Ryan J (1995) Phenotypic variation in boron-toxicity tolerance at seedling stage in durum wheat (Triticum durum). Euphytica 83:185-191

You C-F, Spivack AJ, Smith JH, Gieskes JM (1993) Mobilization of boron in convergent margins: implications for the boron geochemical cycle. Geology 21:207-210

Zeebe RE (2005) Stable boron isotope fractionation between dissolved $\mathrm{B}(\mathrm{OH})_{3}$ and $\mathrm{B}(\mathrm{OH})_{4}$. Geochim Cosmochim Acta 69:2753-2766

Zeebe RE, Bijma J, Hönisch B, Sanyal A, Spero HJ, Wolf-Gladrow DA (2009) Vital effects and beyond: a modeling perspective on developing paleoceanographic proxy relationships in foraminifera Biogeochemical Controls on Palaeoceanographic Proxies. The Geological Society, London, pp in press 